Portland State University

PDXScholar

$1-1-2012$

\title{
Railroaded: The Transcontinentals and the Making of Modern America
}

William L. Lang

Portland State University, langw@pdx.edu

Follow this and additional works at: https://pdxscholar.library.pdx.edu/hist_fac

Part of the United States History Commons

Let us know how access to this document benefits you.

\section{Citation Details}

Lang, W. L. (2012). Railroaded: The Transcontinentals and the Making of Modern America. Oregon Historical Quarterly, 113(1), 111-112.

This Book Review is brought to you for free and open access. It has been accepted for inclusion in History Faculty Publications and Presentations by an authorized administrator of PDXScholar. Please contact us if we can make this document more accessible: pdxscholar@pdx.edu. 
RAILROADED: THE TRANSCONTINENTALS AND THE MAKING OF MODERN AMERICA

by Richard White

W.W. Norton, New York, 2011. Illustrations, maps, graphs, notes, index. 660 pages. $\$ 35.00$ cloth.

Whenever we disdainfully criticize some dysfunctional condition, we often say: "What a way to run a railroad!" That catchphrase rests on an image of railroads as the epitome of efficient and successful enterprises, the gold standard of competency. But what if the management of the most famous of the great nineteenth-century railroads - the transcontinentals - was inefficient, unsuccessful, and incompetent? It is Richard White's conclusion in his new history, Railroaded: The Transcontinentals and the Making of Modern America, that the phrase should be inverted to become a legitimate question - did the industrialists truly run their railroads? - as well as a political and economic description: building the great iron roads from the Midwest to the Pacific Coast was an uneconomic proposition. This book is an intense and intimate investigation of the inner workings of highly leveraged enterprises - the most detailed and revealing we have seen. The author's discoveries and analyses create a storyline that contrasts sharply with the familiar triumphalist saga seen even in recent histories: David Howard Bain, Empire Express (2000), Stephen Ambrose, Nothing Like it in the World (2001), and Walter Borneman, Rival Rails (2010).

White's rendition of the transcontinental story begins with the dream of spanning the continent that enticed nearly everyone. The means, though, became tangled in politics. Enterprising industrial financiers wanted to build the roads without risking their own money, while Congress tried to protect taxpay- ers from footing the bill. Financiers pursued wealth by fashioning an inventive combination of bond issues and accounting deceits. Their shenanigans passed a good portion of the risk and most of the costs on to the government. The prime example of the financial filching by a transcontinental, the Union Pacific Railroad, benefitted from a gullible and bribed Congress that handed the railroad $\$ 43$ million in unearned payments from 1864 to 1893 . The end of the story stood as a bookend to the financial audacities that launched the effort, a vast failure that White labels "Collapse." It was the result of incompetence on a grand a scale, he argues, as immense as the extent of western railroad mileage in 1900. More important for his larger purpose in writing this book, White asks how a disaster that plunged all but one of the transcontinentals into bankruptcy within thirty years can be seen as an example of triumphal industrial capitalism. "Seen from within western railroads and Congress," White concludes, "modernity seemed to me the reverse of the homilies of the Gilded Age: it was the triumph of the unfit, whose survival demanded the intervention of the state, which the corporations themselves corrupted" (p. 509).

White focuses on the synergistic creation of modernity that jelled in the late nineteenth century, the essential casting of an industrial republic that begged for reformulation in the twentieth century. In his hands, the story is not a perverted Darwinian tale of the fit and unfit, but a neo-Darwinian narrative where the American West stands as a geographical stage for the co-evolution of modern corporations and a new industrial state. At more than five hundred pages of text, plus fascinating graphic appendices of financial information, we might ask if the book has to be so massive, as if it needs to match the extent of manipulative finances it details so relentlessly. The answer is 
yes, even if the author's pique is undisguised and his tone, often lilted with biting humor, sometimes conveys a wagging finger of reproach. The length is more justified, though, by the author's method.

It is the revelatory descriptions of individual and often quite personal actions of key actors that carry the narrative. In Railroaded, readers see the developing network of financial schemes and questionable dealings from the viewpoints of major players: Jay Gould, Collis P. Huntington, Leland Stanford, Charles Francis Adams, and many others. The information comes from a deep investigation in manuscript collections that offer personal and business correspondence that amounts to an eavesdropping wiretap on insider collusions. For readers of this journal, White's portrait of Henry Villard, the German-born financier who controlled the Northern Pacific's completion during the early 1880 os, is especially revealing. White details Villard's deceitful practices that scrambled railroad development in the Pacific Northwest and drove the Northern Pacific to the brink of collapse, calling him "a superhero of bad management - powerful, daring, able to destroy railroads at a single blow" (p. 217). Describing Villard's ignominious fall in 1893 , as the Northern Pacific went into receivership, White quotes E.L. Godkin's appraisal of Villard:

He has been kicked out of every enterprise he was connected with here, and is universally denounced as a visionary, if not worse, who has made money at the expense of other people.... The unfortunate truth is that of six companies of which he was forefront, every one has either gone to smash or depreciated enormously in value, and the losers naturally ask how it is that he has so much? How vain is human greatness! (p. 397).

White's emphasis on the financiers' machinations keeps Railroaded from devolving into an institutional history, where faceless corporations elide responsibility. The players, White insists, used other people's money, did so capriciously, and triangulated their deceits by selling an unfounded optimism to the public as they bought cooperation from a willing and aggrandizing political class. To better infuse the story with societal details, the author includes eleven vignettes, short biographies and scenes of social change. After mixing the personal and financial histories of creating the transcontinental railroads, White concludes that we can learn from a clear-eyed accounting of the consequences befalling a nation from unwise decisions, but we can perhaps learn more from contemplating the choices not made, the routes not taken. This account of the building of the transcontinental railroads genuinely alters a stock narrative of western and national history. More than that, it also is an eye-opening cautionary story about the corrosive effect of a co-generative relationship between the power of capital and the structure of government.

William L. LANG Portland State University

\section{NATURE'S NORTHWEST: THE NORTH PACIFIC SLOPE IN THE TWENTIETH CENTURY}

by William G. Robbins and Katrine Barber

The University of Arizona Press, Tucson, 2011. Illustrations, maps, tables, notes, index. 312 pages. \$55.00 cloth. \$24.95 paper.

This is an important book for several reasons. While several histories of the Pacific Northwest already exist, none of their authors concentrates mainly on the region's twentieth-century history. Traditionally, in fact, the region's nineteenth-century history received the most attention because it was during that time that its events were most clearly differentiated from those occurring in the rest of the nation. During the twentieth century, the two histories seemed to blend into one national narrative. But by using the Pacific Northwest's noticeable affinity for nature as their principal organizing 